NUNES, Denise Silva; TYBUSCH, Jerônimo Siqueira. Ecologia política e os deslocados ambientais: uma abordagem reflexiva no contexto latino-americano. Revista Eletrônica Direito e Política, Programa de Pós-Graduação Stricto Sensu em Ciência Jurídica da UNIVALI, Itajaí, v.10, n.1, edição especial de 2015. Disponível em: www.univali.br/direitoepolitica - ISSN 1980-7791.

\title{
ECOLOGIA POLÍTICA E OS DESLOCADOS AMBIENTAIS: UMA ABORDAGEM REFLEXIVA NO CONTEXTO LATINO-AMERICANO
}

\author{
ECOLOGY ENVIRONMENTAL POLICY AND THE DISPLACED PERSONS: A \\ REFLECTIVE APPROACH IN LATIN AMERICAN CONTEXT
}

\author{
Denise Silva Nunes ${ }^{1}$ \\ Jerônimo Siqueira Tybusch²
}

SUMÁRIO: Introdução; 1 . Os deslocados ambientais no cenário da ONU; 2. O deslocamento ambiental decorrente dos conflitos distributivos; 3 . Ecologia Política e a percepção do deslocamento ambiental no contexto latino-americano; 3.1. Ecologia política, desenvolvimento e sustentabilidade; 3.2. Contribuições da ecologia política ao contexto dos deslocados ambientais latino-americano; Considerações Finais; Referências das Fontes Citadas.

RESUMO: A ocorrência cada vez mais freqüente dos desastres naturais e a progressiva degradação do meio ambiente provocam efeitos em cadeia, nos quais nem sempre é possível mensurar as conseqüências, os impactos e dimensões. Destaca-se que cresce a cada dia a 'categoria' dos deslocados ambientais, a qual é nova no cenário internacional e nacional. Assim, o presente

\footnotetext{
1 Mestranda em Direito no Programa de Pós-Graduação em Direito da Universidade Federal de Santa Maria (PPGD/UFSM). Pós-Graduanda no Curso de Especialização em Educação Ambiental e Graduanda no Curso de Ciências Sociais - Bacharelado, pela UFSM. Integrante do Grupo de Pesquisa em Direitos da Sociobiodiversidade (GPDS/UFSM), registrado no Diretório de Grupos do CNPq e certificado pela UFSM. Bolsista CAPES. Graduada em Direito pela Universidade Luterana do Brasil (ULBRA - Santa Maria). Advogada. Endereço eletrônico: denise.silva.nunes@hotmail.com

2 Doutor em Ciências Humanas pela Universidade Federal de Santa Catarina - UFSC (2011); mestre em Direito Público pela Universidade do Vale do Rio dos Sinos - UNISINOS (2007); graduado em Direito pela Universidade de Santa Cruz do Sul - UNISC (2004). Professor Adjunto no Departamento de Direito da Universidade Federal de Santa Maria - UFSM. Professor do Programa de Pós-Graduação em Direito (PPGD/UFSM) - Mestrado em Direito. Professor do Programa de PósGraduação em Tecnologias Educacionais em Rede (PPGTER/UFSM) - Mestrado Profissional em Tecnologias Educacionais em Rede. Professor Pesquisador I - UAB. Coordenador do Projeto Justiça Ambiental em Redes Colaborativas: e-democracy e Ecologia Política na Sociedade Informacional Latino-Americana, contemplado com Auxílio Financeiro Edital Universal CNPq - 2011. Pesquisador e Vice-Líder do Grupo de Pesquisa em Direito da Sociobiodiversidade - GPDS, registrado no Diretório de Grupos do CNPq e certificado pela UFSM. Endereço eletrônico: jeronimotybusch@ufsm.com
} 
NUNES, Denise Silva; TYBUSCH, Jerônimo Siqueira. Ecologia política e os deslocados ambientais: uma abordagem reflexiva no contexto latino-americano. Revista Eletrônica Direito e Política, Programa de Pós-Graduação Stricto Sensu em Ciência Jurídica da UNIVALI, Itajaí, v.10, n.1, edição especial de 2015. Disponível em: www.univali.br/direitoepolitica - ISSN 1980-7791.

artigo objetiva verificar as (prováveis) contribuições da Ecologia Política neste contexto, a fim de contribuir para a análise desse fenômeno de forma reflexiva. Através de uma abordagem sistêmica, busca-se, portanto, a construção de propostas diferenciadas na percepção do fenômeno dos deslocamentos ambientais, face ao cenário complexo e contingente da problemática. Como resultado final, pondera-se que na discussão sobre deslocamento ambiental é necessário discutir a 'cena ecológica' (problemática ambiental), a fim de possibilitar a construção de estratégias de prevenção e combate das múltiplas causas que 'forçam' a mobilidade humana, de forma indesejada, abrupta. Assim, é fundamental que a discussão seja de forma multidimensional.

Palavras-chaves: América Latina; Deslocados ambientais; Ecologia política.

ABSTRACT: The increasingly frequent occurrence of natural disasters and the progressive degradation of the environment cause knock-on effects, in which it is not always possible to measure the consequences, impacts and dimensions. It is noteworthy that grows every day the 'category' of environmental displaced, which is new in the international and national scene. Thus, this article aims to verify the (probable) contributions of Political Ecology in this context, in order to contribute to the analysis of this phenomenon reflexively. Through a systematic approach, we seek to, so the construction of proposals differentiated in the perception of the phenomenon of environmental shifts, given the complex and contingent scenario of the problem. As a final result, considering that in the discussion of environmental displacement is necessary to discuss the 'ecological scene' (environmental issues) in order to enable the construction of strategies to prevent and combat the multiple causes that 'force' human mobility, unwanted, abruptly. It is therefore crucial that the discussion is in a multidimensional way.

Keywords: Latin America; Environmental displaceds; Political ecology.

\section{INTRODUÇÃO}

A mobilidade humana integra a historicidade da humanidade, através da qual o homem, enquanto nômade, buscava a sua sobrevivência em diversos ambientes, por meio de formas de adaptação e utilização dos recursos naturais.

Atualmente, a ocorrência da mobilidade humana pode representar uma espécie de 'fuga'. Os deslocamentos humanos representam uma fuga emergente do ambiente, devido às catástrofes naturais, como tornados, terremotos, etc.

Também podem ocorrer movimentos migratórios no interior de um país, como quando da ocorrência de chuvas, enchentes, ou então pela questão distributiva, 
NUNES, Denise Silva; TYBUSCH, Jerônimo Siqueira. Ecologia política e os deslocados ambientais: uma abordagem reflexiva no contexto latino-americano. Revista Eletrônica Direito e Política, Programa de Pós-Graduação Stricto Sensu em Ciência Jurídica da UNIVALI, Itajaí, v.10, n.1, edição especial de 2015. Disponível em: www.univali.br/direitoepolitica - ISSN 1980-7791.

no que tange à falta de acesso aos recursos naturais, esgotamento dos solos, conflitos agrários, etc.. Este fenômeno vem sendo chamado de 'deslocamento ambiental', em que as pessoas que se deslocam são denominadas por 'refugiados ambientais', contudo, trata-se de uma situação que não se enquadra na convenção jurídica do instituto do refúgio tradicional.

O presente artigo versa sobre os deslocados ambientais na América Latina, e tem como objetivo verificar as (prováveis) contribuições da Ecologia Política neste contexto, a fim de contribuir para a análise desse fenômeno de forma reflexiva.

A metodologia obedece ao trinômio Teoria de Base/Abordagem, Procedimento e Técnica, que se entrelaçam numa relação sistêmico-complexa, de modo a configurar um método que permite abordar o Direito em sinergia com outras áreas do saber, como as Ciências Exatas, Sociais Aplicadas e Ciências Humanas.

Atualmente a 'categoria' dos deslocados ambientais não possui regulamentação jurídica expressa (tanto nacional como internacional), de modo a dificultar a proteção e assistência aos grupos, comunidades e indivíduos deslocados.

A situação é agravada quando se trata de deslocamento para além das fronteiras dos Estados nacionais, visto que este tipo de situação não pode ser enquadrada no instituto do 'refúgio'. Isso porque para o reconhecimento de refúgio são necessários alguns requisitos. Como exemplo, no Brasil a Lei No 9.474/1997 exige a "grave e generalizada violação de direitos humanos; fundados temores de perseguição por motivos de raça, religião, nacionalidade, grupo social ou opiniões políticas; a condição de que se encontre fora de seu país de nacionalidade e não possa ou não queira acolher-se à proteção de tal país"; dentre outros.

Assim, essa nova categoria encontra-se desprotegida juridicamente, necessitando de discussão, seja para a proteção, reconhecimento, cooperação e solidariedade entre os Estados, ou então, na discussão pelas questões distributiva e desenvolvimentista que também fomentam a mobilidade humana. 
NUNES, Denise Silva; TYBUSCH, Jerônimo Siqueira. Ecologia política e os deslocados ambientais: uma abordagem reflexiva no contexto latino-americano. Revista Eletrônica Direito e Política, Programa de Pós-Graduação Stricto Sensu em Ciência Jurídica da UNIVALI, Itajaí, v.10, n.1, edição especial de 2015. Disponível em: www.univali.br/direitoepolitica - ISSN 1980-7791.

Verificam-se a reprodução de desigualdades e a incapacidade dos Estados em conter o crescimento desenfreado que produz impactos ambientais negativos em diversas dimensões, como o caso dos deslocamentos ambientais. Portanto, é necessário buscar uma reinvenção das tradições jurídico-políticas e econômicas, almejando estratégias de emancipação social e a proteção socioambiental.

A análise dos deslocamentos ambientais sob 0 enfoque latino-americano possibilita pensar fora das totalidades ocidentais definidas epistemologicamente. A perspectiva da Ecologia Política possibilita analisar a sociobiodiversidade, e assim, contemplar a preservação da diversidade biológica para a manutenção da vida humana e a preservação cultural, com o uso sustentável dos recursos naturais.

Busca-se, portanto, a construção de propostas diferenciadas na percepção do fenômeno dos deslocamentos ambientais, face ao cenário complexo e contingente da problemática. Para tanto, a abordagem é reflexiva, observando, de forma sistêmica, a comunicação dos diversos sistemas que se entrelaçam com a questão ambiental. Aponta-se a Ecologia Política, enquanto base e sustentação do enfoque principal da pesquisa, devido ao seu grau elevado de interdisciplinaridade.

A presente pesquisa está estruturada em três momentos. Primeiramente, a abordagem consiste na análise dos deslocados ambientais no cenário da ONU. Posteriormente, no segundo momento, o deslocamento ambiental decorrente dos conflitos distributivos. Por fim, no terceiro momento, as contribuições da Ecologia Política na percepção do deslocamento ambiental no contexto latino-americano.

\section{OS DESLOCADOS AMBIENTAIS NO CENÁRIO DA ONU}

A questão dos 'refugiados ambientais' é nova no cenário internacional, embora o fenômeno seja antigo. Refere-se às pessoas que saem de seus países, não por motivos como perseguições de raça, religião, nacionalidade, nem por serem integrantes de um grupo social específico ou por suas opiniões políticas, mas 
NUNES, Denise Silva; TYBUSCH, Jerônimo Siqueira. Ecologia política e os deslocados ambientais: uma abordagem reflexiva no contexto latino-americano. Revista Eletrônica Direito e Política, Programa de Pós-Graduação Stricto Sensu em Ciência Jurídica da UNIVALI, Itajaí, v.10, n.1, edição especial de 2015. Disponível em: www.univali.br/direitoepolitica - ISSN 1980-7791.

sim, por fatores relacionados às mudanças ambientais que tornaram (tornam) suas vidas ameaçadas ou insustentáveis no local onde moravam.

Em alguns casos, essas pessoas encontram novos lugares para viver em seus próprios países. Em outros, acabam mudando de país, buscando refúgio. Calculase, a ONU, que cerca de 25 milhões de pessoas deixaram seus lares devido à seca, desertificação, erosão do solo, acidentes industriais e outras causas ambientais.

A mudança climática, induzida principalmente pelo padrão de consumo com o modelo de produção industrial imposto pelos países desenvolvidos e pelos países industrializados, acelerou os processos naturais e trouxe um novo problema para a seara do Direito Internacional. Isto é, milhares de pessoas deixam o seu Estado, ou região de origem, porque este (s) foi (foram) completamente destruído(s) por eventos naturais exacerbados pelas alterações climáticas.

Os desastres naturais produziram mais refugiados nos últimos anos que as guerras e os conflitos. O aquecimento global e o aumento da temperatura do planeta provocado pela crescente concentração de gases do efeito estufa, resultantes de atividades antropogênicas, como a queima de combustíveis fósseis e o desflorestamento, é um dos principais causadores dos problemas ambientais hoje no mundo, ainda que não seja o único.

Para Érika Pires Ramos, não se trata de um fenômeno novo, já que existem até mesmo relatos bíblicos que noticiam a fuga em razão de calamidades devastadoras. É fato que inúmeras calamidades naturais ocorreram ao longo da história, forçando o deslocamento de indivíduos e grupos para locais mais seguros, visando à própria sobrevivência. ${ }^{3}$

As são pessoas forçadas a deixar seu habitat natural, temporária ou permanentemente, por causa de uma marcante perturbação ambiental (natural

3 RAMOS, Érika Pires. Refugiados ambientais: em busca de reconhecimento pelo direito internacional. Tese de Doutorado. Faculdade de Direito da Universidade de São Paulo (USP). São Paulo, 2011. 
NUNES, Denise Silva; TYBUSCH, Jerônimo Siqueira. Ecologia política e os deslocados ambientais: uma abordagem reflexiva no contexto latino-americano. Revista Eletrônica Direito e Política, Programa de Pós-Graduação Stricto Sensu em Ciência Jurídica da UNIVALI, Itajaí, v.10, n.1, edição especial de 2015. Disponível em: www.univali.br/direitoepolitica - ISSN 1980-7791.

e/ou desencadeada pela ação humana), que colocou em risco sua existência e/ou seriamente afetou sua qualidade de vida.

Por "perturbação ambiental", nessa definição, entendemos quaisquer mudanças físicas, químicas, e/ou biológicas no ecossistema (ou na base de recursos), que o tornem, temporária ou permanentemente, impróprio para sustentar a vida humana. De acordo com esta definição, pessoas deslocadas por razões políticas ou por conflitos civis e migrantes em busca de melhores empregos (por motivos estritamente econômicos) não são consideradas refugiados ambientais. ${ }^{4}$

Existem três grandes categorias de refugiados ambientais: Primeiro, há aqueles que foram deslocados temporariamente por causa de um stress ambiental. A segunda categoria de refugiados ambientais compreende aqueles que tiveram de ser permanentemente deslocados e restabelecidos em uma nova área. A terceira categoria de refugiados ambientais é constituída de indivíduos ou grupos de pessoas que migram de seu habitat original, temporária ou permanentemente, para um novo dentro de suas fronteiras nacionais, ou no exterior, em busca de uma melhor qualidade de vida. ${ }^{5}$

A ONU reconhece a gravidade do problema, mas há uma clara resistência à ampliação do regime internacional convencional existente aos refugiados ambientais, pois não reconhece os fatores ambientais como motivação, por si só, para a concessão do status de refugiado.

O Alto Comissariado das Nações Unidas para Refugiados (ACNUR) reconhece que há grupos de migrantes fora do âmbito de proteção internacional que necessitam de ajuda humanitária e de outras formas de assistência, mas entende que isso não justificaria uma revisão do Estatuto dos Refugiados de 1951. Esta lacuna jurídica, no tocante ao reconhecimento dos refugiados ambientais, favorece a imigração ilegal, o tráfico internacional de pessoas e o aliciamento para atividades criminosas.

\footnotetext{
4 RAMOS, Érika Pires. Refugiados ambientais: em busca de reconhecimento pelo direito internacional.

5 RAMOS, Érika Pires. Refugiados ambientais: em busca de reconhecimento pelo direito internacional, p.77-80.
} 
NUNES, Denise Silva; TYBUSCH, Jerônimo Siqueira. Ecologia política e os deslocados ambientais: uma abordagem reflexiva no contexto latino-americano. Revista Eletrônica Direito e Política, Programa de Pós-Graduação Stricto Sensu em Ciência Jurídica da UNIVALI, Itajaí, v.10, n.1, edição especial de 2015. Disponível em: www.univali.br/direitoepolitica - ISSN 1980-7791.

O refúgio no Brasil já é uma política de Estado. Esta é uma conquista importante e forma parte da construção do edifício dos direitos humanos e, portanto, da democracia deste país. Ao longo de dez anos dever, desde o CONARE ${ }^{6}$, de outorgar - ou não - refúgio aos estrangeiros que o solicitam.

O número de solicitações vem crescendo. Os países de origem estão se diversificando, e o Brasil está se convertendo em um destino seguro para solicitantes de refúgio. Homens e mulheres de 69 nacionalidades receberam o status de refugiado. Ainda mais, o Brasil abriu as portas do reassentamento solidário, sempre no marco do PAM, como um elemento adicional e generoso da proteção internacional. ${ }^{7}$

Recentemente inundações decorrentes de chuvas de proporções inéditas assolaram o Estado de Santa Catarina e, em seguida, parte do norte e o nordeste do País, deixando milhares de desalojados e desabrigados, prejudicando enormemente a economia desses estados e ensejando a migração de indivíduos ali residentes para demais localidades. ${ }^{8}$

A temática sobre os deslocamentos ambientais aos poucos vem sendo inserida nas pautas de reuniões e negociações da Conferência das Partes (ONU). Isso porque os grandes desastres naturais, tais como terremotos, enchentes, etc., repercutem nas mídias (tradicionais e novas mídias) e produzem medo e insegurança na sociedade, bem como resultam em reivindicações pelos movimentos ambientalistas.

\footnotetext{
${ }^{6}$ O CONARE - Comitê Nacional para os Refugiados é o órgão colegiado, vinculado ao Ministério da Justiça, que reúne segmentos representativos da área governamental, da Sociedade Civil e das Nações Unidas, e que tem por finalidade: analisar o pedido sobre o reconhecimento da condição de refugiado; deliberar quanto à cessação "ex officio" ou mediante requerimento das autoridades competentes, da condição de refugiado; declarar a perda da condição de refugiado; orientar e coordenar as ações necessárias à eficácia da proteção, assistência, integração local e apoio jurídico aos refugiados, com a participação dos Ministérios e instituições que compõem o CONARE; e aprovar instruções normativas que possibilitem a execução da Lei no 9.474/97.

${ }^{7}$ LEÃO, Renato Ribeiro. O reconhecimento dos refugiados pelo Brasil: Decisões comentadas do CONARE. 2007, p.8.

${ }^{8}$ BREITWISSER, Liliane Graciele. Refugiados ambientais: breves notas sobre sua proteção jurídica internacional. In. Revista de Direito Ambiental. Ano 14, n.56, 2009, p.146.
} 
NUNES, Denise Silva; TYBUSCH, Jerônimo Siqueira. Ecologia política e os deslocados ambientais: uma abordagem reflexiva no contexto latino-americano. Revista Eletrônica Direito e Política, Programa de Pós-Graduação Stricto Sensu em Ciência Jurídica da UNIVALI, Itajaí, v.10, n.1, edição especial de 2015. Disponível em: www.univali.br/direitoepolitica - ISSN 1980-7791.

Os Estados não são flexíveis e existem dificuldades em firmar consenso rumo à propositura de soluções eficazes na proteção tanto dos deslocados forçados, como também, aos deslocados voluntários.

Destaca-se que, comumente o que mais chama atenção são os deslocamentos forçados resultantes de catástrofes naturais. No entanto, no contexto latinoamericano o que vem ocorrendo com maior abrangência são os deslocamentos resultantes de causas associadas à questão ambiental, como, por exemplo, a procura de novos territórios para garantir a manutenção da vida humana em casos de desertificação, exaurimento dos solos, conflitos agrários, construções de hidrelétricas e obras dos programas desenvolvimentistas, dentre outros.

Importante é romper com os paradigmas que atribuem, de forma radical, as causas dos deslocamentos ambientais por conta das catástrofes naturais (como as alterações climáticas). Faz-se necessário discutir, principalmente, os deslocamentos ambientais resultantes de fatores associados à comunicação ecológica, como a degradação progressiva do meio ambiente e os decorrentes efeitos socioambientais.

Assim, a 'reflexividade' possibilita uma análise aprofundada sobre o contexto dos deslocamentos, permitindo, inclusive, a construção de estratégias e possibilidades de prevenção e combate às múltiplas causas atribuídas aos deslocamentos 'forçados' ou voluntariamente indesejáveis.

Nesse estudo, faz-se necessário analisar outros aspectos que estão inseridos na questão dos deslocamentos ambientais, conforme a seguir.

\section{O DESLOCAMENTO AMBIENTAL DECORRENTE DOS CONFLITOS DISTRIBUTIVOS}

Atualmente, inúmeros desastres ambientais vêm ocorrendo, com destaque para as enchentes, deslizamentos e desmoronamento de construções fixadas nas encostas das cidades. Nesses casos, as populações necessitam se retirar dos 
NUNES, Denise Silva; TYBUSCH, Jerônimo Siqueira. Ecologia política e os deslocados ambientais: uma abordagem reflexiva no contexto latino-americano. Revista Eletrônica Direito e Política, Programa de Pós-Graduação Stricto Sensu em Ciência Jurídica da UNIVALI, Itajaí, v.10, n.1, edição especial de 2015. Disponível em: www.univali.br/direitoepolitica - ISSN 1980-7791.

locais. ${ }^{9}$ O desastre é considerado um fenômeno próprio à dinâmica social e, assim sendo, é no interior da mesma que se identifica os limites da ação técnica para evitar o problema. ${ }^{10}$

O aumento da população nas cidades ${ }^{11}$, muitas vezes em locais impróprios, e/ou não estruturados, faz com que a falta de saneamento básico seja percebida, o que inclui o não fornecimento de água limpa e nem o tratamento de esgoto a todos os moradores dos locais. ${ }^{12}$

O solo possui uma riquíssima proteção natural: a cobertura vegetal. Nela existem organismos que asseguram todo um complexo ciclo biológico. Quando o homem destrói essa proteção, o solo fica exposto à ação de ventos, de chuvas, com direta incidência solar e altas temperaturas, que, além de comprometerem a estrutura viva ali existente, deixam o solo improdutivo, podendo causar perdas por erosões.

A partir do momento em que o indivíduo (enquanto não proprietário dos meios de produção) deixou de ter acesso à terra, à natureza e aos produtos de seu trabalho, ele deixou de se compreender como um ser pertencente ao sistema natural. Desse modo, o elemento emancipação abarcado, por exemplo, nas contribuições de Marx, aparece como uma premente necessidade, no sentido de colaborar e de rever algumas questões como a função do Direito, do lugar dos

9 Quando as populações em periferias encontram-se na condição de desabrigadas, apenas reconfirmam, num nível maior de degradação, a sua inferioridade construída por essa ordem social. O status de desabrigado torna-se, assim, não só um termo definidor de um tipo de carência - a da falta de moradia e acesso à terra - mas um termo estigmatizante dentro da racionalidade hegemônica de manutenção de distâncias sociais e territoriais, e que precisa, sem mais tardar, ser questionado (MARCHEZINI, Victor. Dos desastres da natureza à natureza dos desastres (p.48-58). In. VALÊNCIO, Norma; SIENA, Mariana; MARCHEZINI, Victor. GONÇALVES, Juliano [Orgs.]. Sociologia dos desastres: Construção, interfaces e perspectivas no Brasil. São Carlos: RIMA, 2009, p.45).

${ }^{10}$ MARCHEZINI, Victor. Dos desastres da natureza à natureza dos desastres. 2009, p.37.

${ }^{11} \mathrm{Na}$ Inglaterra, por exemplo, com a Revolução agrícola, todo ano as cidades tinham de receber o que se considerava excedente dos trabalhadores (MARX, 1996b, p.822). Quanto mais rápido se acumula capital numa cidade industrial ou comercial, tanto mais rápido é o afluxo do material humano explorável e tanto mais miseráveis as habitações improvisadas dos trabalhadores (MARX, Karl. O capital: Crítica da economia política. Livro Primeiro - O processo de circulação do capital. V.2. Rio de Janeiro: Civilização Brasileira, 1996b, p.768-769).

12 LANG, Adriana Maria; LINK, Dionísio. Percepção ecossistema vivenciado pelos alunos do $6^{\circ}$ ano da EMEF de Panambi/RS. In. Revista de Monografias Ambientais (REMOA). v.4, n.4, (p. 582595), UFSM, 2011, p.586. 
NUNES, Denise Silva; TYBUSCH, Jerônimo Siqueira. Ecologia política e os deslocados ambientais: uma abordagem reflexiva no contexto latino-americano. Revista Eletrônica Direito e Política, Programa de Pós-Graduação Stricto Sensu em Ciência Jurídica da UNIVALI, Itajaí, v.10, n.1, edição especial de 2015. Disponível em: www.univali.br/direitoepolitica - ISSN 1980-7791.

sujeitos e todo o arcabouço jurídico, no que tange à propositura de soluções para a questão socioambiental.

O uso do solo para além de sua capacidade, ou em áreas proibidas pela legislação, como próximo às margens de cursos d'água ou em áreas declivosas, constitui um conflito de uso, e já existem mapas de conflito de uso para várias áreas. ${ }^{13}$

Algumas regiões apresentam maiores probabilidades de potencializarem efeitos nocivos de mudanças climáticas, por exemplo, agravando os resultados e produzindo verdadeiras catástrofes ambientais em decorrência da carência de estruturas, recursos e orientações básicas para a gestão de emergências nestas situações. ${ }^{14}$

Com o crescimento exagerado das demandas localizadas, ocorre a escassez hídrica, se agravando com a urbanização, industrialização e expansão agrícola. Esse contexto contribui para a intensificação do deslocamento de pessoas.

Os conflitos sociais distributivos envolvem o não reconhecimento e perda de direitos, e no cenário no grupo dos mais vulneráveis estão os povos locais como os indígenas. As perdas pelo não reconhecimento de seus direitos vão desde a negação de sua condição natural de cidadão, por ser o habitante original, nativo, até a negação do espaço pela expropriação de suas terras. ${ }^{15}$

O conflito distributivo introduz na economia política do ambiente as condições ecológicas de sobrevivência e produção sustentável, assim como o conflito social

13 DALMOLIN, Ricardo Simão Diniz; AZEVEDo Antônio Carlos de; PEDRON, Fabrício de Araújo [Orgs.]. Solos e Ambiente: Uma introdução. 2.ed.. Emater-RS, 2006, p.39.

${ }^{14}$ TYBUSCH, Jerônimo Siqueira. A sustentabilidade multidimensional como ação reflexiva para uma ecologia política pós-colonial. In. América Latina e Caribe na encruzilhada ambiental: dimensões política, jurídica e estratégica. Org. Fernando Estenssoro (et.al.). Ijuí, RS: Unijuí, 2011, p.22.

${ }^{15}$ CLAVERO, Bartolomé. Geografia Jurídica de América Latina. Madri, 2008, p.23. 
NUNES, Denise Silva; TYBUSCH, Jerônimo Siqueira. Ecologia política e os deslocados ambientais: uma abordagem reflexiva no contexto latino-americano. Revista Eletrônica Direito e Política, Programa de Pós-Graduação Stricto Sensu em Ciência Jurídica da UNIVALI, Itajaí, v.10, n.1, edição especial de 2015. Disponível em: www.univali.br/direitoepolitica - ISSN 1980-7791.

que emerge das formas dominantes de apropriação da natureza e a contaminação ambiental. ${ }^{16}$

A desigualdade ambiental pode manifestar-se tanto sob a forma de proteção ambiental desigual como de acesso desigual dos recursos ambientais. ${ }^{17}$

A exploração ambiental das populações mais desprotegidas faz da concentração dos males sobre os mais pobres um meio de extração de uma espécie de 'maisvalia ambiental' pela qual os capitais se acumulam pela apropriação dos benefícios do ambiente e pela imposição do consumo forçado de seus efluentes indesejáveis aos mais pobres. Configura-se uma relação lógica entre a acumulação de riqueza e a contaminação do ambiente. Com isso, "certos capitais lucram com a transferência dos males ambientais para os mais desprotegidos". ${ }^{18}$

Marx abordou o trabalho nômade. Uma camada da população, de origem rural, mas cuja ocupação é principalmente industrial. Ela constitui a infantaria ligeira do capital que a lança ora num setor ora noutro, de acordo com suas necessidades. Quando não está em marcha, acampa. ${ }^{19}$

Quando os empreendimentos envolvem muito dispêndio de capital, como ferrovias, etc., o próprio empresário fornece em regra a seu exército barracos de madeira ou construções semelhantes, verdadeiras aldeias improvisadas, sem qualquer preocupação de ordem sanitária, fora do controle das autoridades locais, e altamente rendosas para o empreiteiro que explora duplamente os trabalhadores, como soldados da indústria e como locatários. ${ }^{20}$

\footnotetext{
${ }^{16}$ LEFF, Enrique. Racionalidade ambiental: a reapropriação social da natureza. Tradução de Luís Carlos Cabral. Rio de Janeiro: Civilização Brasileira, 2006, p.302.

17 ACSELRAD, Henri; MELLO, Cecília Campello. O que é Justiça Ambiental. Rio de Janeiro: Garamond, 2009, p.73.

${ }^{18}$ ACSELRAD, Henri; MELLO, Cecília Campello. O que é Justiça Ambiental. p.77.

19 O trabalho nômade é empregado em diversas atividades de construção e de drenagem, na produção de tijolos, para queimar cal, na construção de ferrovias, etc. É uma coluna pestilencial que se desloca levando para as cidades em cujas proximidades se instalam varíola, tifo, cólera, escarlatina, etc. (MARX, Karl. 0 capital: Crítica da economia política. Livro Primeiro, V.2. p.772).

${ }^{20}$ MARX, Karl. O capital: Crítica da economia política. Livro Primeiro. V.2. p.772.
} 
NUNES, Denise Silva; TYBUSCH, Jerônimo Siqueira. Ecologia política e os deslocados ambientais: uma abordagem reflexiva no contexto latino-americano. Revista Eletrônica Direito e Política, Programa de Pós-Graduação Stricto Sensu em Ciência Jurídica da UNIVALI, Itajaí, v.10, n.1, edição especial de 2015. Disponível em: www.univali.br/direitoepolitica - ISSN 1980-7791.

Se uma população trabalhadora excedente é produto necessário da acumulação ou do desenvolvimento da riqueza no sistema capitalista, ela se torna, por sua vez, a alavanca da acumulação capitalista, bem como a ('e mesmo'), condição de existência do modo de produção capitalista. Ela constitui um exército industrial de reserva disponível, que pertence ao capital de maneira tão absoluta como se fosse criado e mantido por ele. ${ }^{21}$

$\mathrm{Na}$ Inglaterra, por exemplo, com a Revolução agrícola, todo ano as cidades tinham de receber o que se considerava excedente dos trabalhadores. ${ }^{22}$ Quanto mais rápido se acumula capital numa cidade industrial ou comercial, tanto mais rápido é o afluxo do material humano explorável e tanto mais miseráveis as habitações improvisadas dos trabalhadores.

Quando a produção da agricultura se apodera da agricultura ou nela vai penetrando, diminui, à medida que se acumula o capital que nela funciona, a procura absoluta da população trabalhadora rural. Dá-se uma repulsão de trabalhadores que não é 'contrabalanceada' por maior atração, como ocorre na indústria 'não-agrícola'. ${ }^{23}$

Por isso, parte da população rural encontra-se sempre na iminência de transferir se para as fileiras do proletariado urbano ou da manufatura e na espreita de circunstâncias favoráveis a essa transferência. Assim, o trabalhador rural é rebaixado ao nível mínimo de salário e está sempre com um pé no pântano do pauperismo. $^{24}$

A miséria da população rural constitui a base de gigantescas fábricas de camisas, etc., com exércitos de trabalhadores na sua maioria esparsos pelos campos. Encontramos ai, o trabalho a domicílio, que cria trabalhadores supérfluos por meio de salários de fome e de trabalho excessivo. ${ }^{25}$

\footnotetext{
${ }^{21}$ MARX, Karl. O capital: Crítica da economia política. Livro Primeiro. V.2, p.733-734.

22 MARX, Karl. O capital: Crítica da economia política. Livro Primeiro. V.2, p.822.

23 MARX, Karl. O capital: Crítica da economia política. Livro Primeiro. V.2, p.745.

24 MARX, Karl. O capital: Crítica da economia política. Livro Primeiro. V.2, p.745.

${ }^{25}$ MARX, Karl. O capital: Crítica da economia política. Livro Primeiro. V.2. p.819.
} 
NUNES, Denise Silva; TYBUSCH, Jerônimo Siqueira. Ecologia política e os deslocados ambientais: uma abordagem reflexiva no contexto latino-americano. Revista Eletrônica Direito e Política, Programa de Pós-Graduação Stricto Sensu em Ciência Jurídica da UNIVALI, Itajaí, v.10, n.1, edição especial de 2015. Disponível em: www.univali.br/direitoepolitica - ISSN 1980-7791.

Nesse contexto, a imposição de um sistema jurídico em que se leva em conta a apropriação individual da propriedade conforme os cânones da ordem liberal, impossível de ser aplicado aos povos indígenas, pois na sua visão de mundo, ao conceber suas sociedades, só admitem a propriedade no sentido coletivo. ${ }^{26}$

$\mathrm{Na}$ seara dos conflitos distributivos podem-se citar movimentos sociais como os de resistência ao neoliberalismo e o da justiça ambiental. Esse último defende a existência de desigualdades em termos de proteção ambiental no planeta. "É, justamente, nas áreas de maior carência socioeconômica que se concentram os maiores déficits em investimentos nas áreas de saneamento, moradia e análise geomorfológica. Compreende-se, portanto, que o risco ambiental não é distribuído proporcionalmente". 27

Frente ao estudo dos deslocamentos ambientais decorrentes de fatores associados às causas ambientais, como a questão distributiva, "a ecologia política se estabelece no campo dos conflitos pela reapropriação da natureza e da cultura", onde a natureza e a cultura resistem à homologação de valores e processos (simbólicos, ecológicos, políticos) incorporáveis e a serem absorvidos em termos de valor de mercado. ${ }^{28}$

Assim, necessário é analisar o campo da Ecologia Política, devido ao seu grau elevado de interdisciplinaridade, conforme se propõe a seguir.

\footnotetext{
${ }^{26}$ ARAÚJO, Luiz Ernani Bonesso de. O direito da sociobiodiversidade. In. Direitos emergentes na sociedade global: Anuário do Programa de Pós-Graduação em Direito da UFSM. Org. TYBUSCH, Jerônimo (et.al.). Ijuí, RS: Unijuí, 2013, p.281.

${ }^{27}$ TYBUSCH, Jerônimo Siqueira. Ecologia Política, sustentabilidade e Direito. p.250.

${ }^{28}$ LEFF, Enrique. Racionalidade ambiental: A reapropriação social da natureza. Trad. Luís Carlos Cabral. Rio de Janeiro: Civilização Brasileira, 2006, p. 303-304.
} 
NUNES, Denise Silva; TYBUSCH, Jerônimo Siqueira. Ecologia política e os deslocados ambientais: uma abordagem reflexiva no contexto latino-americano. Revista Eletrônica Direito e Política, Programa de Pós-Graduação Stricto Sensu em Ciência Jurídica da UNIVALI, Itajaí, v.10, n.1, edição especial de 2015. Disponível em: www.univali.br/direitoepolitica - ISSN 1980-7791.

\section{ECOLOGIA POLÍtiCA E A PERCEPÇÃO do DESLOCAMENTO AMBIENTAL NO CONTEXTO LATINO-AMERICANO}

A Ecologia Política é o campo de estudo dos conflitos socioambientais, e remete ao estudo dos conflitos ecológicos distributivos. Constitui-se um campo criado por geógrafos, antropólogos e sociólogos ambientais. ${ }^{29}$

Introduzida em 1957 por Bertrand de Jouvenel e, posteriormente, aprofundada em seus contornos teóricos por Eric Wolf ${ }^{30}$ a expressão 'ecologia política' é utilizada para demarcar semanticamente um campo de lutas, estudos e práticas em construção.

A atribuição de sentidos não hegemônicos à ecologia política parte necessariamente da superação da ideia de "dominação da natureza", que subjaz ao desenvolvimento científico e tecnológico contemporâneo. A construção de uma perspectiva latino-americana da ecologia política "exige repensar os fundamentos da matriz de racionalidade eurocêntrica". ${ }^{31}$

$\mathrm{Na}$ perspectiva pós-colonial a cultura é observada como estratégia de sobrevivência tanto transnacional como tradutória. Tradução no sentido de que as histórias espaciais de deslocamento (acompanhadas das disputas territoriais e tecnologias globais e midiáticas) priorizam como a cultura significa e é significada. Assim, os discursos naturalizados como "unificadores" de povos e nações não podem ter referências imediatas. Tal perspectiva desperta consciência acerca da "construção da cultura e da invenção da tradição". ${ }^{32}$

O pensamento pós-moderno redefine os sujeitos como nômades. Baseado nas experiências de migrantes, artistas e exilados, e sem levar muito em contam as estruturas econômicas e socioculturais, os fluxos de mensagens e bens que

${ }^{29}$ MARTÍNEZ-ALIER. O ecologismo dos pobres: conflitos ambientais e linguagens de valoração. Tradução de Maurício Waldman. São Paulo: Contexto, 2007, p. 15.

30 MARTÍNEZ-ALIER. $\mathbf{O}$ ecologismo dos pobres: conflitos ambientais e linguagens de valoração. p. 110.

31 PORTO-GONÇALVES, Carlos Walter. A globalização da natureza e a natureza da globalização. 3.ed. Rio de Janeiro: Civilização Brasileira, 2012, p. 6.

32 BHABHA, Homi K. O local da cultura. Tradução de Myriam Ávila; Gláucia Gonçalves e Eliana de Lima Reis. Belo Horizonte: Editora UFGM, 1998, p.238. 
NUNES, Denise Silva; TYBUSCH, Jerônimo Siqueira. Ecologia política e os deslocados ambientais: uma abordagem reflexiva no contexto latino-americano. Revista Eletrônica Direito e Política, Programa de Pós-Graduação Stricto Sensu em Ciência Jurídica da UNIVALI, Itajaí, v.10, n.1, edição especial de 2015. Disponível em: www.univali.br/direitoepolitica - ISSN 1980-7791.

possibilitam a experiência nômade, estes autores exaltam a desterritorialização e veem o enfraquecimento dos laços de pertencimento nacionais ou locais como uma libertação (Deleuze, Guattari, Lyotard). Em vez das estruturas duráveis de sentimentos, a relocalização tática de experiências e condutas, e esta desconstrução dos sujeitos ensimesmados e conscientes, ligados a um território, radicalizam-se num mundo em rede. ${ }^{33}$

As identidades dos sujeitos formam-se agora em processos interéticos e internacionais, entre fluxos produzidos pelas tecnologias e as corporações multinacionais. Hoje, imaginamos o que significa ser sujeitos não só a partir da cultura em que nascemos mas também de uma enorme variedade de repertórios simbólicos e modelos de comportamento. ${ }^{34}$

No contexto dos deslocamentos ambientais é imprescindível a discussão sobre o modelo atual de vida, o qual atualmente é definido como insustentável. E essa constatação se deve a inúmeras questões, como ponto de partida, a relação 'homem-natureza' e as interações desta relação.

$\mathrm{Na}$ discussão sobre deslocamento ambiental é necessário discutir a 'cena ecológica' (problemática ambiental), a fim de possibilitar a construção de estratégias de prevenção e combate das múltiplas causas que 'forçam' a mobilidade humana, de forma indesejada, abrupta.

Assim, "nasce, portanto, o sentimento de proteção a 'futuras existências'. O sentimento da possível finitude humana produz requestionamentos acerca da humanidade enquanto continuum de seu projeto". ${ }^{35}$ Ou melhor, faz-se necessário discutir a interface desenvolvimento e sustentabilidade.

33 CANCLINI, Nestor García. Diferentes, desiguais e desconectados: mapas da interculturalidade. Tradução de Luiz Sérgio Henriques. 3.ed. Rio de Janeiro: Editora UFRJ, 2009, p.202.

34 CANCLINI, Nestor García. Diferentes, desiguais e desconectados: mapas da interculturalidade. p.201.

35 TYBUSCH, Jerônimo Siqueira. Ecologia Política, sustentabilidade e Direito. In. Direitos emergentes na sociedade global: Anuário do Programa de Pós-Graduação em Direito da UFSM. Organizador Jerônimo Tybusch. [et al.]. Ijuí, RS: Unijuí, 2013, p.224. 
NUNES, Denise Silva; TYBUSCH, Jerônimo Siqueira. Ecologia política e os deslocados ambientais: uma abordagem reflexiva no contexto latino-americano. Revista Eletrônica Direito e Política, Programa de Pós-Graduação Stricto Sensu em Ciência Jurídica da UNIVALI, Itajaí, v.10, n.1, edição especial de 2015. Disponível em: www.univali.br/direitoepolitica - ISSN 1980-7791.

\subsection{Ecologia política, desenvolvimento e sustentabilidade}

O termo "sustentável" foi primordialmente trabalhado ainda na década de 70 , pela comunidade científica, sendo utilizado para designar a possibilidade de um ecossistema não perder sua resiliência. Após esse momento, o termo foi utilizado nos anos 80 , para qualificar o termo 'desenvolvimento'. ${ }^{36}$

O desenvolvimento sustentável' possui raízes no Relatório Brundtland ou "Nosso Futuro Comum", publicado em 1987 na Comissão Mundial sobre o Meio Ambiente e Desenvolvimento.

A 'questão ambiental' ocupa na atualidade um lócus privilegiado na produção discursiva do pensamento ocidental, em face das preocupações oriundas da probabilidade de esgotamento dos recursos naturais, e, por consequência, a existência de riscos como possibilidades de danos futuros em decorrência de decisões particulares. ${ }^{37}$

Nesse sentido, verifica-se a existência de dúvidas na administração de ações que envolvam ecologia e meio ambiente, as quais são produzidas por indivíduos, empresas, indústrias, e dos sistemas como Economia, Política e Direito.

$\mathrm{Na}$ análise das forças produtivas, uma contradição, uma luta e um conflito passam ao primeiro plano, ou seja, a constante luta do homem contra a natureza. ${ }^{38}$

Cada dia esse sistema (capitalista) contribui para a fome, para os conflitos distributivos, para os constantes desmatamentos, para a seca, para o extermínio de culturas, para a subjugação de povos, para a falta de qualidade de vida, para a extinção de diversas espécies da fauna, para a contaminação do ar, rios, solos, etc..

Os sistemas econômicos e produtivos se desenvolveram há três séculos sem levar em conta a sua incompatibilidade com o sistema ecológico. Hoje nos damos

\footnotetext{
36 VEIGA, José Eli da. Sustentabilidade: A legitimação de um novo valor. São Paulo: SENAC, 2010, p.12.

37 TYBUSCH, Jerônimo Siqueira. Ecologia Política, sustentabilidade e Direito. p.224-225.

38 LEFEBVRE, Henri. Marxismo. Tradução de William Lagos. Porto Alegre: L\&PM, 2011, p.72.
} 
NUNES, Denise Silva; TYBUSCH, Jerônimo Siqueira. Ecologia política e os deslocados ambientais: uma abordagem reflexiva no contexto latino-americano. Revista Eletrônica Direito e Política, Programa de Pós-Graduação Stricto Sensu em Ciência Jurídica da UNIVALI, Itajaí, v.10, n.1, edição especial de 2015. Disponível em: www.univali.br/direitoepolitica - ISSN 1980-7791.

conta de que ecologia e modo industrialista de produção, que implica no saque desertificante da natureza, são, de fato, contraditórios. ${ }^{39}$

O autor Enrique Leff entende que se tem uma tentativa equivocada de reconciliar dois aspectos contraditórios da dialética do desenvolvimento, na percepção do meio ambiente e do crescimento econômico. ${ }^{40}$

Nessa perspectiva, o autor Leonardo Boff menciona que atrás da expressão 'desenvolvimento sustentável' se escondem oportunidades e também muitos equívocos perigosos, isto é:

(1) A categoria desenvolvimento provém da área da economia política dominante, que é capitalista. Obedece a lógica férrea da maximalização dos benefícios com a minimização dos custos e o encurtamento maior possível do tempo empregado. Procura-se extrair da Terra, literalmente, tudo o que é consumível e sendo apropriado privadamente. O resultado é uma produção fantástica de bens materiais e serviços, mas distribuídos desigualmente, gerando injustiça social mundial. (2) A categoria da sustentabilidade provém do âmbito da biologia e da ecologia. Ela traduz a tendência dos ecossistemas ao equilíbrio dinâmico, à cooperação e à coevolução, e responde pelas interdependências de todos com todos, garantindo a inclusão de cada ser, até dos mais fracos. ${ }^{41}$

Com estes apontamentos explicativos, Leonardo Boff entende que unir sustentabilidade com desenvolvimento configura uma contradição nos próprios termos. Pois, "eles têm lógicas que se autonegam: uma privilegia o individuo, a outra, o coletivo; uma enfatiza a competição, a outra, a cooperação; uma a evolução do mais apto, a outra, a coevolução de todos juntos e interrelacionados". ${ }^{42}$

\footnotetext{
39 BOFF, Leonardo. Cuidar da Terra, proteger a vida: Como evitar o fim do mundo. Rio de Janeiro: Record, 2010. p.296.

40 LEFF, Enrique. Ecologia, capital e cultura: a territorialização da racionalidade ambiental. Petrópolis, RJ: Vozes, 2009, p.239.

${ }^{41}$ BOFF, Leonardo. Cuidar da Terra, proteger a vida: Como evitar o fim do mundo. p.201.

42 BOFF, Leonardo. Cuidar da Terra, proteger a vida: Como evitar o fim do mundo. p.201-202.
} 
NUNES, Denise Silva; TYBUSCH, Jerônimo Siqueira. Ecologia política e os deslocados ambientais: uma abordagem reflexiva no contexto latino-americano. Revista Eletrônica Direito e Política, Programa de Pós-Graduação Stricto Sensu em Ciência Jurídica da UNIVALI, Itajaí, v.10, n.1, edição especial de 2015. Disponível em: www.univali.br/direitoepolitica - ISSN 1980-7791.

$\mathrm{Na}$ perspectiva da racionalidade ambiental e da sustentabilidade, é necessário observar a comunicação ecológica, a qual implica em considerar a comunicação relativa às interações de todos os elementos constituintes de um ecossistema.

Desse modo, pensar na comunicação do meio ambiente significa considerar as interações ocorridas na natureza conjugada à ação antrópica. Significa observar as modificações na 'natureza verde' pelo homem, desde as primeiras ações até a constituição do espaço urbanizado, por exemplo.

[...] compreende-se que existe uma maior influência do saber e poder econômicos na comunicação ecológica. Pois, "as práticas discursivas, no que tangem a questão ambiental, partem, na realidade das políticas públicas, de orientações desenvolvimentistas, resultando em ações que operam a partir de uma lógica de custo e benefício ou de um código valor/não-valor para, em um segundo momento, tentar adequá-las na perspectiva da sustentabilidade. ${ }^{43}$

Nesse contexto, verifica-se a dificuldade metodológica na aplicabilidade do conceito de desenvolvimento sustentável e também na formulação de uma técnica jurídica eficiente, no sentido de incorporar as diversas dimensões da sustentabilidade.

O crescimento econômico, sem o devido respeito ao direito fundamental ao meio ambiente limpo e ecologicamente sadio, provoca danos irreparáveis ou de difícil reparação. ${ }^{44}$

Sobre o conflito que envolve o conceito de 'desenvolvimento' é possível aferir uma duplicidade, onde, de um lado, a perspectiva da razão instrumental como elemento impulsionador do crescimento econômico e da acumulação, fomentando processos exploratórios. De outro lado, as correntes que defendem uma racionalidade calcada na construção histórica e fundamentada em processos de equidade e justiça social. ${ }^{45}$

\footnotetext{
${ }^{43}$ TYBUSCH, Jerônimo Siqueira. Ecologia Política, sustentabilidade e Direito. p.225.

${ }^{44}$ FREITAS, Juarez. Sustentabilidade: Direito ao futuro. 2.ed. Belo Horizonte: Editora Fórum, 2012, p.44.

${ }^{45}$ RIBEIRO, Gustavo Lins. Ambientalismo e desenvolvimento sustentado: nova ideologia/utopia do desenvolvimento. (p.59-101). In: Revista de Antropologia. N.34. São Paulo: USP, 1991, p.61.
} 
NUNES, Denise Silva; TYBUSCH, Jerônimo Siqueira. Ecologia política e os deslocados ambientais: uma abordagem reflexiva no contexto latino-americano. Revista Eletrônica Direito e Política, Programa de Pós-Graduação Stricto Sensu em Ciência Jurídica da UNIVALI, Itajaí, v.10, n.1, edição especial de 2015. Disponível em: www.univali.br/direitoepolitica - ISSN 1980-7791.

$\mathrm{Na}$ atualidade, as correntes de desenvolvimento encaminham-se para a percepção de uma estrutura de desenvolvimento includente como oposição à padronização do crescimento perverso. ${ }^{46}$

No que tange ao conceito de desenvolvimento e a sua relação com o subdesenvolvimento na América Latina, o autor Celso furtado enfatiza que a problemática possui obstáculos de natureza institucional. Este contexto impulsiona os povos latino-americanos a se conhecerem de forma mais sistemática valorizando os delineamentos para a constituição de uma personalidade comum. ${ }^{47}$

Nesse sentido, o autor Eduardo Devés Valdés percebe em sua abordagem 'Pensamento Latino-americano', o pensamento inovador de Celso Furtado o qual apresentou caminhos para a compreensão dos problemas específicos do subdesenvolvimento. ${ }^{48}$

Nesse esquema de uma teoria do subdesenvolvimento, Furtado aponta para uma série de aspectos particulares. Por exemplo, define as 'estruturas subdesenvolvidas' como aquelas que estão conformadas por setores ou departamentos dotados de comportamentos específicos. As estruturas subdesenvolvidas são desarticuladas e heterogêneas e não reagem nem se ajustam com a mesma fluidez com que o fazem as desenvolvidas. ${ }^{49}$

$\mathrm{Na}$ análise dos processos de subdesenvolvimento, os países subdesenvolvidos ou em desenvolvimento produzem cada vez mais dívidas, com a reprodução das desigualdades, com normas ambientais enfraquecidas, e estruturas que atuam conforme a racionalidade do comércio internacional.

\footnotetext{
${ }^{46}$ TYBUSCH, Jerônimo Siqueira. Ecologia Política, sustentabilidade e Direito. p.228.

47 FURTADO, Celso. A economia latino-americana: formação histórica e problemas contemporâneos. 4.ed. São Paulo: Companhia das Letras, 2007, p.25.

${ }^{48}$ TYBUSCH, Jerônimo Siqueira. Ecologia Política, sustentabilidade e Direito. p.231.

${ }^{49}$ No original: "En este esquema de una teoría el subdesarrollo, Furtado apunta a una serie de aspectos particulares. Por ejemplo, define 'las estructuras subdesarrolladas' como aquellas que están conformadas por sectores o departamentos dotados de comportamientos específicos. Las estructuras subdesarrolladas son desarticuladas y heterogêneas, y no reaccionan ni se ajustan com La misma fluidez com que lo hacen las desarrolladas". (DEVÉS-VÁLDES, Eduardo. El pensamiento latinoamericano en el siglo XX: desde la Cepal al neoliberalismo 1950-1990. 1.ed. Buenos Aires: Biblos, 2003, p.31).
} 
NUNES, Denise Silva; TYBUSCH, Jerônimo Siqueira. Ecologia política e os deslocados ambientais: uma abordagem reflexiva no contexto latino-americano. Revista Eletrônica Direito e Política, Programa de Pós-Graduação Stricto Sensu em Ciência Jurídica da UNIVALI, Itajaí, v.10, n.1, edição especial de 2015. Disponível em: www.univali.br/direitoepolitica - ISSN 1980-7791.

O sistema de competitividade faz com que as empresas de fora sejam conduzidas a atrair investimentos nos países latino-americanos, com a circulação e fluidez do capital global.

A competição desenfreada dos capitalistas uns com os outros, em torno da busca do maior lucro, acarreta um grave desperdício de recursos. ${ }^{50} \mathrm{~A}$ batalha da concorrência é conduzida por meio da redução dos preços das mercadorias, e os capitais grandes esmagam os pequenos. ${ }^{51}$

A crise ecológica implica dois desequilíbrios básicos no nível social: o excesso de consumo dos ricos e a carência dos pobres. Conforme Leonardo Boff, "ela significa a crise global do sistema de vida, desde a destruição das florestas, a proliferação das neuroses urbanas, até o cinismo contemporâneo face ao drama de milhões de famintos". ${ }^{52}$

A lógica da crise é que existe a velocidade de construir e destruir relações para a alimentação do sistema, onde o mercado nunca é harmônico nas suas relações, ele sempre necessita alargar seus horizontes para conseguir atingir o estado cíclico do sistema (permanecendo a crise).

Conforme explica Tybusch, na economia de mercado o investimento em produtos com alto valor agregado conduz à inovação tecnológica e o aumento da especialização técnica dos trabalhadores. ${ }^{53} \mathrm{E}$, em contrapartida, "a produção primária com baixo investimento em mão de obra, legislação ambiental 'fraca' e esgotamento dos recursos naturais conduz, fatalmente, à estagnação econômica". 54

Muitas vezes, destaca-se que na situação de miserabilidade, quando não se tem as necessidades básicas garantidas, é reduzida (ou inexistente) a capacidade do

\footnotetext{
50 KONDER, Leandro. O que é dialética. São Paulo: Brasiliense,1985, p.33.

${ }^{51}$ MARX, Karl. O capital: Crítica da economia política. Livro Primeiro. V.2, p.727.

52 BOFF, Leonardo. Cuidar da Terra, proteger a vida: Como evitar o fim do mundo. p.116.

53 TYBUSCH, Jerônimo Siqueira. Ecologia Política, sustentabilidade e Direito. p.233.

54 TYBUSCH, Jerônimo Siqueira. Ecologia Política, sustentabilidade e Direito. p.233.
} 
NUNES, Denise Silva; TYBUSCH, Jerônimo Siqueira. Ecologia política e os deslocados ambientais: uma abordagem reflexiva no contexto latino-americano. Revista Eletrônica Direito e Política, Programa de Pós-Graduação Stricto Sensu em Ciência Jurídica da UNIVALI, Itajaí, v.10, n.1, edição especial de 2015. Disponível em: www.univali.br/direitoepolitica - ISSN 1980-7791.

indivíduo em utilizar os recursos de maneira sustentável, e de se preocupar com outras questões ambientais.

O desenvolvimento includente demanda, principalmente, participação e democracia, a fim de possibilitar a construção (consolidação e eficácia) de garantias para o exercício dos direitos civis, políticos, etc.. Também é necessário perceber os efeitos de uma problemática 'socioambiental'.

O desenvolvimento na perspectiva de Sachs ${ }^{55}$, não pode ser visto em separado do crescimento econômico, e, por si só, este não garante aquele. Em outras palavras, o mau desenvolvimento pode ser evidenciado onde é possível verificar somente o crescimento do Produto Interno Bruto (PIB) dos países em desenvolvimento, percebendo-se o aumento do desemprego, pobreza e desigualdades sociais.

Percebe-se que existe uma configuração idealizada para o conceito de desenvolvimento. $\mathrm{Na}$ realidade, as estratégias de apropriação dos recursos naturais dos países em desenvolvimento e subdesenvolvidos, na perspectiva da globalização econômica, legitimam seus discursos na retórica do desenvolvimento sustentável.

A ligação entre liberdade individual e realização de desenvolvimento social vai muito além da relação constitutiva - por mais importante que ela seja. O que as pessoas conseguem positivamente realizar é influenciado por oportunidades econômicas, liberdades políticas, poderes sociais e por condições habilitadoras como: boa saúde, educação básica e, incentivo e aperfeiçoamento de iniciativas. As disposições institucionais pelo exercício das liberdades das pessoas, mediante a liberdade para participar da escolha social e da tomada de decisões públicas que impelem o progresso dessas oportunidades. ${ }^{56}$

55 SACHS, Ignacy. Caminhos para o Desenvolvimento Sustentável. 3. ed. Rio de Janeiro: Garamond, 2008, p.71.

56 SEN, Amartya Kumar. Desenvolvimento como liberdade. Tradução de Laura Teixeira Motta. São Paulo: Companhia das Letras, 2000, p.19. 
NUNES, Denise Silva; TYBUSCH, Jerônimo Siqueira. Ecologia política e os deslocados ambientais: uma abordagem reflexiva no contexto latino-americano. Revista Eletrônica Direito e Política, Programa de Pós-Graduação Stricto Sensu em Ciência Jurídica da UNIVALI, Itajaí, v.10, n.1, edição especial de 2015. Disponível em: www.univali.br/direitoepolitica - ISSN 1980-7791.

Principalmente nos países em desenvolvimento, como nos subdesenvolvidos, as lutas também consistem na busca pelo desenvolvimento includente e desenvolvimento como liberdade.

A ideologia do desenvolvimento sustentável desencadeia, assim, um delírio e uma inércia incontrolável de crescimento. O discurso da sustentabilidade aparece como um simulacro que nega os limites do crescimento, para afirmar a corrida desenfreada até a morte entrópica do planeta. O neoliberalismo ambiental planeja acima de toda lei de conservação e reprodução social para dar curso a processos que ultrapassam toda a norma, referencial e sentido para controlá-los. Se as estratégias do ecodesenvolvimento surgiram como resposta à crise ambiental, a retórica da sustentabilidade opera como uma estratégia fatal, uma inércia cega, uma precipitação para a catástrofe. ${ }^{57}$

Existe dificuldade em superar as contradições fundamentais do sistema capitalista, principalmente no que diz respeito à tendência em apropriar-se de forma degenerativa dos recursos naturais e do meio ambiente. A 'questão ambiental' é reduzida à sistemática econômica, a valores de mercado traduzidos nas codificações do capital.

O objetivo de abrangência intergeracional, o alcance da justiça e equidade sociais, bem como a proteção ecológica propriamente dita, ficam prejudicados em face dos interesses do sistema econômico. ${ }^{58}$

O pensamento economicista dominante no mundo capitalista global, a questão ambiental soluciona-se através do estabelecimento de valores monetários aos bens e serviços ambientais. ${ }^{59}$

O desenvolvimento sustentável inserido nas condições do modo de produção capitalista representa um equívoco. As causas reais da pobreza e da degradação resultam exatamente do tipo de desenvolvimento praticado. Esse modelo é o que

\footnotetext{
57 LEFF, Enrique. Ecologia, capital e cultura: a territorialização da racionalidade ambiental. Petrópolis, RJ: Vozes, 2009, p. 236.

58 TYBUSCH, Jerônimo Siqueira. Ecologia Política, sustentabilidade e Direito. p. 13.

59 TYBUSCH, Jerônimo Siqueira. Ecologia Política, sustentabilidade e Direito. p.239.
} 
NUNES, Denise Silva; TYBUSCH, Jerônimo Siqueira. Ecologia política e os deslocados ambientais: uma abordagem reflexiva no contexto latino-americano. Revista Eletrônica Direito e Política, Programa de Pós-Graduação Stricto Sensu em Ciência Jurídica da UNIVALI, Itajaí, v.10, n.1, edição especial de 2015. Disponível em: www.univali.br/direitoepolitica - ISSN 1980-7791.

produz a degradação, pois, dilapida a natureza em seus recursos (consome em excesso) e explora a força de trabalho ao pagar baixos salários, gerando pobreza e exclusão social. ${ }^{60}$

O trabalho permitiu ao homem dominar algumas das energias da natureza; permitiu-Ihe - como escreveu o brasileiro José Arthur Giannotti - ter parte da natureza à sua disposição. ${ }^{61}$

A partir da divisão social do trabalho, a humanidade passava a ter uma dificuldade bem maior para pensar os seus próprios problemas e para encará-los de um ângulo mais amplamente universal. ${ }^{62}$

É por essa razão que a utilização política da expressão desenvolvimento sustentável representa uma armadilha do sistema imperante: assume os termos da Ecologia (sustentabilidade) para esvaziá-los e assume o ideal da Economia (o desenvolvimento), mascarando, porém, a pobreza, as desigualdades e a devastação ambiental que ele mesmo produz. A fórmula desenvolvimento sustentável no quadro da economia dominante capitalista significa uma ilusão. Postula-se um desenvolvimento que se move entre dois infinitos: o infinito dos recursos da Terra e o infinito do futuro. ${ }^{63}$

Entender tal equívoco ('desenvolvimento sustentável') é verificar o porquê das desigualdades e da destruição da natureza. A sustentabilidade deve ser livre de seu condicionamento capitalista e do desenvolvimento, ora considerado apenas em si mesmo. Assim sendo, a sustentabilidade deve ser garantida, primeiramente, à Terra, à humanidade como um todo e a cada pessoa. Essa é a pré-condição sem a qual não há o desenvolvimento sustentável. ${ }^{64}$

É necessário pensar a questão ambiental para além da perspectiva do desenvolvimento tradicional. É preciso compreender um caráter multidimensional do desenvolvimento, bem como da sustentabilidade. "Todo o processo

\footnotetext{
60 BOFF, Leonardo. Cuidar da Terra, proteger a vida: Como evitar o fim do mundo. p.202.

61 KONDER, Leandro. 0 que é dialética. p. 24.

62 KONDER, Leandro. 0 que é dialética. p. 30.

${ }^{63}$ BOFF, Leonardo. Cuidar da Terra, proteger a vida: Como evitar o fim do mundo. p.202.

${ }^{64}$ BOFF, Leonardo. Cuidar da Terra, proteger a vida: Como evitar o fim do mundo. p.203.
} 
NUNES, Denise Silva; TYBUSCH, Jerônimo Siqueira. Ecologia política e os deslocados ambientais: uma abordagem reflexiva no contexto latino-americano. Revista Eletrônica Direito e Política, Programa de Pós-Graduação Stricto Sensu em Ciência Jurídica da UNIVALI, Itajaí, v.10, n.1, edição especial de 2015. Disponível em: www.univali.br/direitoepolitica - ISSN 1980-7791.

sustentável tem como fundamento o território como elemento no qual se cristalizam as bases ecológicas e as identidades culturais". ${ }^{65}$

Por uma perspectiva de se pensar a sustentabilidade de forma ampla, e interligada a outros fatores, que o autor Juarez Freitas defende que existe uma natureza pluridimensional: social, ética, jurídico-política, econômica e ambiental. ${ }^{66}$

Ao introduzir as diversas dimensões da sustentabilidade, o autor Juarez Freitas ${ }^{67}$ propõe preencher algumas lacunas encontradas em torno do conceito, uma vez que na acepção generalizada permitem-se inúmeros desvirtuamentos e considerações, que sempre pendem para o viés econômico, ignorando outros aspectos inerentes à sustentabilidade.

A sustentabilidade implica num aspecto multidimensional. As suas dimensões (econômica, social, ambiental, ética, jurídico-política) se entrelaçam e se pressupõe que elas devam "ser tratadas em sincronia, com transparência, e o atraso de uma dimensão acarreta forçosamente o atraso das demais". ${ }^{68}$

A sustentabilidade pensada em suas diversas dimensões torna-se princípio norteador de todas as relações. Trabalhar a sustentabilidade com um viés multidimensional auxilia na superação de sua vinculação restrita aos aspectos essencialmente econômicos de crescimento, e contribui para a superação dos efeitos negativos em cadeia do modelo de desenvolvimento (crescimento perverso).

O cenário que engloba a percepção de crise ambiental, onde é possível verificar suas mazelas ao longo da história, coloca a humanidade diante do desafio de abdicar a ideologia do progresso vinculado ao atual modelo de desenvolvimento, instaurado a partir da sociedade capitalista moderna.

\footnotetext{
${ }^{65}$ TYBUSCH, Jerônimo Siqueira. Ecologia Política, sustentabilidade e Direito. p.241.

${ }^{66}$ FREITAS, Juarez. Sustentabilidade: Direito ao futuro. p.55.

${ }^{67}$ FREITAS, Juarez. Sustentabilidade: Direito ao futuro.

${ }^{68}$ FREITAS, Juarez. Sustentabilidade: Direito ao futuro. p.310.
} 
NUNES, Denise Silva; TYBUSCH, Jerônimo Siqueira. Ecologia política e os deslocados ambientais: uma abordagem reflexiva no contexto latino-americano. Revista Eletrônica Direito e Política, Programa de Pós-Graduação Stricto Sensu em Ciência Jurídica da UNIVALI, Itajaí, v.10, n.1, edição especial de 2015. Disponível em: www.univali.br/direitoepolitica - ISSN 1980-7791.

Busca-se construir uma nova racionalidade ambiental na sociedade. Para tanto, o caráter pluridimensional da sustentabilidade representa uma possibilidade no enfrentamento da crise socioambiental.

\subsection{Contribuições da ecologia política ao contexto dos deslocados ambientais latino-americano}

Os desafios do desenvolvimento sustentável implicam na necessidade de formar cidadãos capacitados, com saberes, técnicas, proporcionando a participação nos processos de produção, construindo uma racionalidade ambiental. Assim, urge a necessidade de alteração de conduta por parte da sociedade, colocando o problema como uma questão que se afigura também como sendo 'ética e cultural'.

Com isso, essa estratégia induz nas culturas locais um pensamento global que nada mais que o discurso economicista do crescimento sustentável, quando o desafio da sustentabilidade "é pensar as singularidades locais e construir uma racionalidade capaz de integrar diferenças, assumindo sua incomensurabilidade, sua relatividade e sua incerteza". ${ }^{69}$

Conforme Enrique Leff , "a globalização econômica e o discurso dominante da sustentabilidade, em sua esquizofrenia discursiva e sua cegueira institucionalizada, desvalorizam estes esforços por construir um saber que integra conhecimentos e valores". ${ }^{70}$ Com isso, o conhecimento, como uma forma de relação com o mundo, foi cooptado pelo interesse prático. E o saber ficou reduzido ao propósito de resolver os problemas ambientais por meio de instrumentos tecnológicos e econômicos. ${ }^{71}$

Por certo, de um modo ou outro a problemática meio ambiental aparece ligada a muitas outras: pobreza,

69 LEFF, Enrique. Ecologia, capital e cultura: a territorialização da racionalidade ambiental. p. 275 .

70 LEFF, Enrique. Racionalidade ambiental: a reapropriação social da natureza. p.187.

${ }^{71}$ LEFF, Enrique. Racionalidade ambiental: a reapropriação social da natureza. p.187. 
NUNES, Denise Silva; TYBUSCH, Jerônimo Siqueira. Ecologia política e os deslocados ambientais: uma abordagem reflexiva no contexto latino-americano. Revista Eletrônica Direito e Política, Programa de Pós-Graduação Stricto Sensu em Ciência Jurídica da UNIVALI, Itajaí, v.10, n.1, edição especial de 2015. Disponível em: www.univali.br/direitoepolitica - ISSN 1980-7791.

marginalidade, papel do Estado e sentido das políticas ecológicas; sub-regiões do espaço latino-americano, questões urbanas e identidades. Mesmo em tom menor, a defesa do meio ambiente se transforma em uma defesa da identidade e vice-versa. De algum modo, a identidade não é somente cultura, senão também se faz etnia, natureza, meio ambiente e patrimônio genético. O tema do meio ambiente vem sendo tópico privilegiado para apocalípticos, 'finisecularis' e utópicos, transformando-se não somente em tema de trabalhos, senão também em uma questão de sensibilidade para uma parte de nossa intelectualidade. ${ }^{72}$

Ocorre que o sistema econômico se apropria do conceito 'desenvolvimento sustentável', apenas reduzindo a questão ambiental à perspectiva do meio ambiente material. Por consequência, desconsidera as identidades culturais, as singularidades "e a autonomia diante da obrigatoriedade imposta por uma globalização dominadora". ${ }^{73}$

No Sul, a reprodução dos padrões de consumo do Norte em benefício de uma pequena minoria resultou em uma apartação social. Na perspectiva de democratização do desenvolvimento, o paradigma necessita ser completamente mudado. Por princípio, o Sul poderia ter evitado alguns dos problemas que estamos atravessando no Norte se tivesse pulado etapas em direção à economia de recursos, orientada para os serviços e menos intensamente materializados, em prol do meio ambiente e da elevação do padrão de pobreza. No entanto, é improvável que isso aconteça sem sinais claros de mudanças no Norte em relação ao efeito demonstrativo dos seus padrões de consumo sobre a população do Sul, maximizados pelos processos de globalização em âmbito cultural. ${ }^{74}$

\footnotetext{
72 No original: "Por cierto, de un modo u otro, la problemática medioambiental aparece ligada a muchas otras: pobreza, marginalidad, papel del Estado y sentido de las políticas ecologistas; subregiones del espacio latinoamericano, cuestiones urbanas e identidad. Aunque en tono menor, la defensa de medio ambiente se transforma en una defensa de la identidad y viceversa. De algún modo, la identidad no es sólo cultura, sino también se hace etnia, naturaleza, medio ambiente y patrimonio genético. El tema del medio ambiente ha sido tópico privilegiado para apocalípticos, 'finiseculares' y utópicos, transformándose no sólo en un tema de trabajo sino también en una cuestión de sensibilidad para una parte de nuestra intelectualidad". (DEVÉS-VALDÉS, Eduardo. EI pensamiento latinoamericano en el siglo XX: las discusiones y las figuras del fin de siglo. Los anos 90. Buenos Aires: Biblos, 2004, p. 188).

73 LEFF, Enrique. Ecologia, capital e cultura: a territorialização da racionalidade ambiental. p. 276.

${ }^{74}$ SACHS, Ignacy. Caminhos para o Desenvolvimento Sustentável. p. 58.
} 
NUNES, Denise Silva; TYBUSCH, Jerônimo Siqueira. Ecologia política e os deslocados ambientais: uma abordagem reflexiva no contexto latino-americano. Revista Eletrônica Direito e Política, Programa de Pós-Graduação Stricto Sensu em Ciência Jurídica da UNIVALI, Itajaí, v.10, n.1, edição especial de 2015. Disponível em: www.univali.br/direitoepolitica - ISSN 1980-7791.

As epistemologias do Sul são o conjunto de intervenções epistemológicas que denunciam essa supressão, valorizam os saberes que resistiram com êxito e investigam as condições de um diálogo horizontal entre conhecimentos. ${ }^{75}$

Tal concepção permite a construção de diálogos e processos democráticos conscientes acerca da questão ambiental. Na realidade, diálogo de saberes em construção, o que leva a questionar a rivalização de formas distintas de conhecimento, entre o conhecimento científico submetido aos interesses hegemônicos da globalização e os saberes culturais das populações tradicionais latino-americanas. ${ }^{76}$

Em termos geopolíticos, trata-se de sociedades periféricas do sistema mundial moderno onde a crença na ciência moderna é mais ténue, onde é mais visível a vinculação da ciência moderna aos desígnios da dominação colonial e imperial. E onde outros conhecimentos não científicos e nãoocidentais prevalecem nas práticas quotidianas das populações. ${ }^{77}$

A formação de um pensamento que supere o imenso abismo entre norte e sul deve ultrapassar a produção de ausências em nossa racionalidade ocidental dominante. Para o autor Boaventura de Sousa Santos essas ausências constituem-se em monoculturas (como culturas únicas e absolutas). ${ }^{78}$

Outro fator que, igualmente, impulsiona a observação da ecologia de saberes é a proliferação de alternativas/possibilidades que formam a globalização contrahegemônica.

A ideia de 'justiça ambiental' é compreendida como a condição de existência social configurada através do tratamento justo e do envolvimento significativo de todas as pessoas, independentemente de sua raça, cor ou renda no que diz

\footnotetext{
75 SANTOS; MENESES; 2009a, p. 13.

76 TYBUSCH, Jerônimo Siqueira. Ecologia Política, sustentabilidade e Direito. p.246.

77 SANTOS, Boaventura de Sousa. Para além do Pensamento Abissal: das linhas globais a uma ecologia de saberes, 2009, p. 47.

78 SANTOS, Boaventura de Sousa. Para além do Pensamento Abissal: das linhas globais a uma ecologia de saberes. p.29.
} 
NUNES, Denise Silva; TYBUSCH, Jerônimo Siqueira. Ecologia política e os deslocados ambientais: uma abordagem reflexiva no contexto latino-americano. Revista Eletrônica Direito e Política, Programa de Pós-Graduação Stricto Sensu em Ciência Jurídica da UNIVALI, Itajaí, v.10, n.1, edição especial de 2015. Disponível em: www.univali.br/direitoepolitica - ISSN 1980-7791.

respeito à elaboração, desenvolvimento, implementação e aplicação de políticas, leis e regulações ambientais. ${ }^{79}$

Neste contexto, vem se configurando um discurso reinvindicativo sobre a ideia de dívida ecológica, como um imaginário e um conceito estratégico dentro dos movimentos de resistência à globalização do mercado e seus instrumentos de coerção financeira, questionando a legitimidade da dívida econômica dos países pobres, boa parte deles na América Latina. A dívida ecológica põe a descoberto a parte mais perversa, e até agora oculta, do intercâmbio desigual entre países ricos e pobres, quer dizer, a destruição da base de recursos naturais dos países 'subdesenvolvidos' cujo estado de pobreza não é consubstancial à uma essência cultural ou à sua limitação de recursos, mas resulta de sua inserção em uma racionalidade econômica global que superexplorou sua natureza, degradou seu ambiente e empobreceu seus povos. ${ }^{80}$

No ciclo de exploração e dependência, no âmbito latino-americano, verificam-se toda uma série de desigualdades e, por consequência, de discriminações raciais, de gênero ou classe social. ${ }^{81}$

Importante também é analisar os direitos da sociobiodiversidade e os deslocados ambientais. No tocante aos direitos da sociobiodiversidade. Conforme Luis Ernani Bonesso de $A$ raújo ${ }^{82}$ remete à relação entre o ser humano e natureza, na qual práticas sociais de produção ou de vivencia comunitária revelam modelos próprios e específicos no trato com a biodiversidade, ou seja, comunidades cuja cultura é fruto da convivência harmônica e sustentável com o seu entorno ambiental.

Nesse contexto, as políticas públicas são imprescindíveis para a relação entre o meio ambiente e o consumo consciente. É importante que as políticas mundiais

\footnotetext{
79 ACSELRAD \& MELLO. O que é Justiça Ambiental. p. 16.

80 LEFF, Enrique. Racionalidade ambiental: a reapropriação social da natureza. p. 303.

81 SACHS, Ignacy. Caminhos para o Desenvolvimento Sustentável. p.38-39.

82 ARAÚJO, Luiz Ernani Bonesso de. O direito da sociobiodiversidade. p.279.
} 
NUNES, Denise Silva; TYBUSCH, Jerônimo Siqueira. Ecologia política e os deslocados ambientais: uma abordagem reflexiva no contexto latino-americano. Revista Eletrônica Direito e Política, Programa de Pós-Graduação Stricto Sensu em Ciência Jurídica da UNIVALI, Itajaí, v.10, n.1, edição especial de 2015. Disponível em: www.univali.br/direitoepolitica - ISSN 1980-7791.

deem mais atenção ao estado degradado da Terra e façam políticas globais de regeneração e de salvamento, para não chegarmos tarde demais. ${ }^{83}$

A cidadania, enquanto ação participativa onde há interesse público ou interesse social, conforme o autor Paulo Affonso Leme Machado implica: "Ser cidadão é sair de sua vida meramente privada e interessar-se pela sociedade de que faz parte e ter direitos e deveres para nela influenciar e decidir". ${ }^{84}$

A problemática ambiental afeta as condições de sustentabilidade do Planeta, de modo que é necessário internalizar as bases ecológicas e os princípios jurídicos e sociais para a gestão adequada e democrática dos recursos naturais, bem como a cidadania e a comunhão de saberes

A gestão ambiental participativa propõe, além da oportunidade de reverter os custos ecológicos e sociais da crise econômica e ecológica, a possibilidade de integrar a população marginalizada num processo de produção para satisfazer suas necessidades fundamentais, aproveitando o potencial ecológico de seus recursos ambientais e respeitando suas identidades coletivas.

Assim sendo, o autor Enrique Leff elenca princípios como condições de uma gestão democrática do desenvolvimento sustentável, tais como: a equidade social, a diversidade cultural, o equilíbrio regional, a autonomia e capacidade de autogestão das comunidades e a pluralidade de tipos de desenvolvimento. ${ }^{85}$

Quanto às políticas para a sustentabilidade no ambiente urbano, por exemplo, faz-se necessário, inclusive, observar a gestão ambiental da cidade, a qual necessita da conjugação da democracia, cidadania e participação, como princípios norteadores para uma gerência administrativa direcionada às questões socioambientais do espaço urbano.

\footnotetext{
83 BOFF, Leonardo. Cuidar da Terra, proteger a vida: Como evitar o fim do mundo. p.206.

84 MACHADO, Paulo Affonso Leme. Direito ambiental brasileiro. 18.ed. rev. atual. São Paulo: Malheiros Editores, 2010, p.139.

85 LEFF, Enrique. Saber ambiental: sustentabilidade, racionalidade, complexidade, poder. Tradução de Lúcia Mathilde Orth. Petrópolis, RJ: Vozes, 2001, p.63.
} 
NUNES, Denise Silva; TYBUSCH, Jerônimo Siqueira. Ecologia política e os deslocados ambientais: uma abordagem reflexiva no contexto latino-americano. Revista Eletrônica Direito e Política, Programa de Pós-Graduação Stricto Sensu em Ciência Jurídica da UNIVALI, Itajaí, v.10, n.1, edição especial de 2015. Disponível em: www.univali.br/direitoepolitica - ISSN 1980-7791.

Temos de desenvolver urgentemente a capacidade de somar, de interagir, de religar, de repensar, de refazer o que foi desfeito e de inovar. Assim, "da articulação de todos esses cacos de saber redesenharemos o painel global da realidade a ser compreendida, amada e cuidada". ${ }^{86}$ Essa totalidade é o conteúdo principal da consciência planetária, essa, sim, a era da luz maior que nos liberta da cegueira que nos aflige.

\section{CONSIDERAÇÕES FINAIS}

O alto teor de degradação que se encontra a natureza deve-se ao voraz e indigno sistema capitalista, o qual desde sua origem fomenta a produção (e sua reprodução) em larga escala, sem a preocupação plena às condições humanas de trabalho e de sobrevivência, e quiçá com qualquer desfragmentação dos recursos naturais. A natureza tornou-se matéria-prima constantemente explorada; uma força produtiva; um mero objeto nas mãos do homem e a serviço do capital.

De forma breve, acerca dos deslocamentos ambientais é possível fazer alguns apontamentos sobre os principais desafios, como a necessidade de analisar a governança dos Estados (nos âmbitos nacional, regional e internacional); a produção discursiva referente à racionalidade econômica e sustentabilidade; o enfrentamento da questão jurídica no que tange ao reconhecimento da nova 'categoria de deslocados ambientais'; os procedimentos de proteção aos deslocados como políticas públicas no âmbito interno dos Estados; etc.

Também é importante a perspectiva da Ecologia Política, a qual também remete à perspectiva da justiça ambiental, no sentido de promover o desenvolvimento justo e includente, com a superação dos impactos ambientais e da repartição desigual dos custos e riscos ecológicos, resultantes dos empreendimentos dos programas desenvolvimentistas, industriais ou comerciais.

\footnotetext{
${ }^{86}$ BOFF, Leonardo. Cuidar da Terra, proteger a vida: Como evitar o fim do mundo. p. 259.
} 
NUNES, Denise Silva; TYBUSCH, Jerônimo Siqueira. Ecologia política e os deslocados ambientais: uma abordagem reflexiva no contexto latino-americano. Revista Eletrônica Direito e Política, Programa de Pós-Graduação Stricto Sensu em Ciência Jurídica da UNIVALI, Itajaí, v.10, n.1, edição especial de 2015. Disponível em: www.univali.br/direitoepolitica - ISSN 1980-7791.

A ecologia política possibilita analisar o fenômeno dos deslocamentos ambientais, pois, ela produz a ressignificação das interações humanas com o meio ambiente, no próprio cenário paradigmático da economia capitalista.

No contexto latino-americano, importante será a construção de diálogos, com processos democráticos conscientes na direção de um senso comum, por meio da formação de percepção (e ideias) que supere $(\mathrm{m})$ o abismo fomentado pela globalização hegemônica, sendo capaz de ultrapassar a produção de ausências nessa racionalidade ocidental dominante.

O autor José Saramago fez da 'cegueira' tema para críticas severas à sociedade atual, assentada sobre uma visão reducionista da realidade. Também nesse sentido, a maioria dos especialistas, chefes de Estado, etc., se encontram enclausurados em seus saberes específicos, nos quais são competentes, mas que, por isso mesmo, se fazem cegos para os gritantes problemas globais. ${ }^{87}$

Com as transformações e novas categorias, "a questão agora não é mais de desenvolvimento, mas de política e de uma nova moralidade: buscar caminhos e valores que vão criando alternativas mais benfazejas para a Terra e para a humanidade, quer dizer, que se tornem mais sustentáveis". ${ }^{88}$

O desafio, entretanto, é conseguir uma sociedade sustentável. Uma sociedade é considerada sustentável quando consegue atender às suas necessidades, mantendo o capital natural, com a sua capacidade de reposição, garantindo condições para que as gerações futuras possam também atender a suas demandas.

É importante, portanto, buscar a percepção do lugar híbrido atribuído aos valores culturais onde a "metáfora da "linguagem" traz à tona a questão da diferença e

\footnotetext{
${ }^{87}$ Nessa perspectiva, Leonardo Boff, ao discorrer sobre "A sociedade mundial da cegueira", alerta para a totalidade do destino humano e o futuro da biosfera: "Há muitos presumidos videntes que são cegos e poucos cegos que são videntes. Hoje se propala pomposamente que vivemos sob a sociedade do conhecimento, uma espécie de nova era das luzes. Conhecemos cada vez menos. [...] O que está em jogo é a totalidade do destino humano e o futuro da biosfera". (BOFF, Leonardo. Cuidar da Terra, proteger a vida: Como evitar o fim do mundo. p.257).

${ }^{88}$ BOFF, Leonardo. Cuidar da Terra, proteger a vida: Como evitar o fim do mundo. p.204.
} 
NUNES, Denise Silva; TYBUSCH, Jerônimo Siqueira. Ecologia política e os deslocados ambientais: uma abordagem reflexiva no contexto latino-americano. Revista Eletrônica Direito e Política, Programa de Pós-Graduação Stricto Sensu em Ciência Jurídica da UNIVALI, Itajaí, v.10, n.1, edição especial de 2015. Disponível em: www.univali.br/direitoepolitica - ISSN 1980-7791.

incomensurabilidade culturais". ${ }^{89}$ Tal compreensão possibilita o (re)questionar das noções etnocêntricas e consensuais da existência pluralista da diversidade cultural.

O ideal é chegarmos a um 'modo sustentável de viver', um ideal proposto pela Carta da Terra, que é bom para a Terra e a todos que habitam nela. Busca-se criar uma vida pessoal sustentável. ${ }^{90}$

Cada geração encontra, legada pela geração anterior, determinada estrutura social organizada, determinado estatuto de propriedade, determinadas relações sociais de produção. ${ }^{91}$ Também encontra determinadas forças sociais produtivas, desenvolvidas até um certo ponto que foi alcançado no tempo da geração precedente. $^{92}$

Cada modo de produção conheceu um crescimento, um apogeu, um declínio e uma crise terminal (sem contar suas crises internas, momentâneas ou mais profundas, no decurso desse desenvolvimento). A história de cada modo de produção se desenvolveu através de múltiplos conflitos. ${ }^{93}$

Provavelmente os deslocamentos ambientais serão os maiores desafios impostos à humanidade. Portanto, os deslocamentos ambientais, sejam por questões naturais (desastres naturais) ou por questões associadas à degradação do meio ambiente representam uma problemática inserida na 'cena ecológica' que está intimamente relacionada ao modo de se relacionar com a natureza. E esta constatação vai desde a formação dos Estados Latino-Americanos, até a

${ }^{89}$ BHABHA, Homi K. O local da cultura. p. 247.

${ }^{90}$ BOFF, Leonardo. Cuidar da Terra, proteger a vida: Como evitar o fim do mundo. p.204.

91 O conjunto das instituições e das ideias resultantes dos eventos e das iniciativas individuais, dentro do esquema de uma estrutura social determinada, foi determinado por Marx de superestrutura dessa sociedade. A superestrutura comporta, portanto, em particular: as instituições jurídicas e políticas, as ideologias, os fetiches ideológicos, etc. A superestrutura é a expressão (através das interações complexas dos indivíduos) do modo de produção, isto é dos relacionamentos com a propriedade (LEFEBVRE, Henri. Marxismo. p.74).

92 KONDER, Leandro. Marxismo e alienação: Contribuição para um estudo do conceito marxista de alienação. 2.ed. São Paulo: Expressão Popular, 2009, p.50.

${ }^{93}$ LEFEBVRE, Henri. Marxismo. p.72. 
NUNES, Denise Silva; TYBUSCH, Jerônimo Siqueira. Ecologia política e os deslocados ambientais: uma abordagem reflexiva no contexto latino-americano. Revista Eletrônica Direito e Política, Programa de Pós-Graduação Stricto Sensu em Ciência Jurídica da UNIVALI, Itajaí, v.10, n.1, edição especial de 2015. Disponível em: www.univali.br/direitoepolitica - ISSN 1980-7791.

composição dos sistemas - Econômico, Político, Social, Cultural que se interpenetram retratando no contexto da atualidade.

E, ao sistema do Direito é permitido estar aberto a essa perspectiva, por meio de uma análise reflexiva frente à percepção meramente 'cartesiana' e das lacunas da técnica-jurídica atual (e tradicional). Busca-se, portanto, a construção de propostas diferenciadas na percepção do fenômeno dos deslocamentos ambientais, face ao cenário complexo e contingente da problemática.

\section{REFERÊNCIAS DAS FONTES CITADAS}

ACSELRAD, Henri (Org.). Conflitos ambientais no Brasil. Rio de Janeiro: Relumé Dumará; Fund. Heinrich Boll, 2004 a.

; MELLO, Cecília Campello do A.; BESERRA, Gustavo das Neves. O que

é Justiça Ambiental. Rio de Janeiro: Garamond, 2009.

AYALA, Patrick de Araújo. Deveres de proteção e o direito fundamental a ser protegido em face de riscos de alimentos transgênicos. Tese de Doutorado, Florianópolis, UFSC, 2009.

ARAÚJO, Luiz Ernani Bonesso de. TYBUSCH, Jerônimo Siqueira. Direitos da sociobiodiversidade e sustentabilidade. In. Direitos Humanos, Relações Internacionais e Meio Ambiente. Daniel Cenci e Gilmar Bedin (Orgs.). Curitiba, PR: Multideia, 2013.

. O direito da sociobiodiversidade. In. Direitos emergentes na sociedade global: anuário do programa de pós-graduação em direito da UFSM. Organizador Jerônimo Tybusch. [et al.]. Ijuí, RS: Unijuí, 2013.

BARLOW, Maude. Água, Pacto Azul: a crise global da água e a batalha pelo controle da água potável no mundo. São Paulo: M.Books do Brasil LTDA, 2009.

BECK, Ulrich. A reinvenção da política: rumo a uma teoria da modernização reflexiva. In: BECK, Ulrich; GIDDENS, Anthony; LASH, Scott. Modernização Reflexiva. São Paulo: Editora da Universidade Estadual Paulista, 1997.

BHABHA, Homi K. O local da cultura. Tradução de Myriam Ávila; Gláucia Gonçalves e Eliana de Lima Reis. Belo Horizonte: Editora UFGM, 1998.

BOFF, Leonardo. Cuidar da Terra, proteger a vida: Como evitar o fim do mundo. Rio de Janeiro: Record, 2010. 
NUNES, Denise Silva; TYBUSCH, Jerônimo Siqueira. Ecologia política e os deslocados ambientais: uma abordagem reflexiva no contexto latino-americano. Revista Eletrônica Direito e Política, Programa de Pós-Graduação Stricto Sensu em Ciência Jurídica da UNIVALI, Itajaí, v.10, n.1, edição especial de 2015. Disponível em: www.univali.br/direitoepolitica - ISSN 1980-7791.

BRASIL. Alto Comissariado das Nações Unidas para os refugiados (ACNUR). Estatuto dos Refugiados. Disponível em: <http://www.acnur.org.br/> Acesso: 25 jun.2014.

A ONU e os refugiados. Disponível em: <http://www.onu.org.br/aonu-em-acao/a-onu-e-os-refugiados/> Acesso: 25 jun.2014.

BREITWISSER, Liliane Graciele. Refugiados ambientais: breves notas sobre sua proteção jurídica internacional. Revista de Direito Ambiental (p.142-166). Ano 14 , n.56, out-dez./2009.

BRUZZONE, Elsa. Las guerras del agua. América del Sur, en la mira de las grandes potencias. 1.ed. Buenos Aires: Capital Intelectual, 2009.

CANCLINI, Nestor García. Diferentes, desiguais e desconectados: mapas da interculturalidade. Tradução de Luiz Sérgio Henriques. 3.ed. Rio de Janeiro: Editora UFRJ, 2009.

Consumidores e Cidadãos. Rio de Janeiro: Editora UFRJ, 2006.

CLAVERO, Bartolomé. Geografia Jurídica de América Latina. Madri, 2008.

DALMOLIN, Ricardo Simão Diniz; AZEVEDO Antônio Carlos de; PEDRON, Fabrício de Araújo [Orgs.]. Solos e Ambiente: Uma introdução. 2.ed., Emater-RS, 2006.

DEVÉS-VALDÉS, Eduardo. El pensamiento latinoamericano en el siglo XX: las discusiones y las figuras del fin de siglo. Los anos 90. Buenos Aires: Biblos, 2004.

El pensamiento latinoamericano en el siglo XX: desde la Cepal al neoliberalismo 1950-1990. 1.ed. Buenos Aires: Biblos, 2003.

FREITAS, Juarez. Sustentabilidade: Direito ao futuro. 2.ed. Belo Horizonte: Editora Fórum, 2012.

FURTADO, Celso. A economia latino-americana: formação histórica e problemas contemporâneos. 4.ed. São Paulo: Companhia das Letras, 2007.

GIDDENS, Anthony. A Terceira Via: Reflexões sobre o impasse político atual e o futuro da social democracia. Rio de Janeiro: Record, 1991.

As consequências da modernidade. São Paulo: Editora UNESP,

2008.

GRASSI, L. A. T. Direito a água. Associação Brasileira de Engenharia Sanitária e Ambiental, Porto Alegre, no 21, mar. 2004. Disponível em:< http://www.abes-rs.org.br/rechid/direito-a-agua.htm>. Acesso em: 25 jun. 2014.

KONDER, Leandro. Marxismo e alienação: Contribuição para um estudo do conceito marxista de alienação. 2.ed. São Paulo: Expressão Popular, 2009. 
NUNES, Denise Silva; TYBUSCH, Jerônimo Siqueira. Ecologia política e os deslocados ambientais: uma abordagem reflexiva no contexto latino-americano. Revista Eletrônica Direito e Política, Programa de Pós-Graduação Stricto Sensu em Ciência Jurídica da UNIVALI, Itajaí, v.10, n.1, edição especial de 2015. Disponível em: www.univali.br/direitoepolitica - ISSN 1980-7791.

O que é dialética. São Paulo: Brasiliense, 1985.

LANG, Adriana Maria; LINK, Dionísio. Percepção ecossistema vivenciado pelos alunos do $6^{\circ}$ ano da EMEF de Panambi/RS. In. Revista de Monografias Ambientais (REMOA). v.4, n.4, (p. 582-595), UFSM, 2011.

LEÃO, Renato Ribeiro, 0 reconhecimento dos refugiados pelo Brasil: Decisões comentadas do CONARE. 2007. Disponível em < http://www.acnur.org/biblioteca/pdf/5780.pdf?view=1>. Acesso em: 20 set.2014.

LEFEBVRE, Henri. Marxismo. Tradução de William Lagos. Porto Alegre: L\&PM, 2011.

LEFF, Enrique. Racionalidade ambiental: a reapropriação social da natureza. Trad. Luís Carlos Cabral. Rio de Janeiro: Civilização Brasileira, 2006.

Saber ambiental: sustentabilidade, racionalidade, complexidade, poder. Trad. Lúcia Mathilde Orth. Petrópolis, RJ: Vozes, 2001, p.63.

Ecologia, capital e cultura: a territorialização da racionalidade ambiental. Petrópolis, RJ: Vozes, 2009.

LITLLE, Paul E. Ecologia Política como Etnografia: um guia teórico e metodológico. Horizontes Antropológicos. Porto Alegre, ano 12, n. 25, 2006.

MACHADO, Paulo Affonso Leme. Direito ambiental brasileiro. 18.ed. rev. atual. São Paulo: Malheiros Editores, 2010.

MARCHEZINI, Victor. Dos desastres da natureza à natureza dos desastres. (p.4858). In. VALENCIO, Norma; SIENA, Mariana; MARCHEZINI, Victor. GONÇALVES, Juliano [Orgs.]. Sociologia dos desastres: Construção, interfaces e perspectivas no Brasil. São Carlos: RIMA, 2009.

MARTÍNEZ-ALIER, Joan. Introducción a la economía ecológica. Cuadernos de Medio Ambiente. Rubens: Barcelona, 1999.

- O ecologismo dos pobres: conflitos ambientais e linguagens de valoração. Tradução de Maurício Waldman. São Paulo: Contexto, 2007.

MARX, Karl. O Capital: crítica da economia política. Livro Primeiro - O processo de produção de capital. v.1. 28.ed. Tradução de Reginaldo Sant'Anna. Rio de Janeiro: Civilização Brasileira, 2011a.

O capital: Crítica da economia política. Livro Primeiro - O processo de circulação do capital. v.2. Rio de Janeiro: Civilização Brasileira, 1996b.

MILARÉ, Édis. Direito do ambiente. 3.ed. São Paulo: Revista dos Tribunais, 2004. 
NUNES, Denise Silva; TYBUSCH, Jerônimo Siqueira. Ecologia política e os deslocados ambientais: uma abordagem reflexiva no contexto latino-americano. Revista Eletrônica Direito e Política, Programa de Pós-Graduação Stricto Sensu em Ciência Jurídica da UNIVALI, Itajaí, v.10, n.1, edição especial de 2015. Disponível em: www.univali.br/direitoepolitica - ISSN 1980-7791.

MORIN, Edgar; KERN, Anne Brigitte. Terra-pátria. Tradução de Paulo Neves. Porto Alegre: Sulina, 2003.

Ciência com consciência. Tradução de Maria Alice Sampaio Dória. 5 ed. Rio de Janeiro: Bertrand Brasil, 2001 a.

MOSCOVICI, Serge. Natureza para pensar a ecologia. Tradução de Marie Louise de Beissac e Regina Mathieu. Rio de Janeiro: Instituto Gaia, 2007.

PORTO-GONÇALVES, Carlos Walter. A globalização da natureza e a natureza da globalização. 3.ed. Rio de Janeiro: Civilização Brasileira, 2012.

RAMOS, Érika Pires. Refugiados ambientais: em busca de reconhecimento pelo direito internacional. Tese de Doutorado. Faculdade de Direito da USP. São Paulo, 2011. Disponível em <http://www.revistas.usp.br/pea/article/view/55946>. Acesso: 2 set. 2014.

RIBEIRO, Gustavo Lins. Ambientalismo e desenvolvimento sustentado: nova ideologia/utopia do desenvolvimento. In: Revista de Antropologia. São Paulo: USP, n.34 (p.59-101),1991.

SACHS, Ignacy. Caminhos para o Desenvolvimento Sustentável. 3. ed. Rio de Janeiro: Garamond, 2008,

SANTOS, Boaventura de Sousa. Para além do Pensamento Abissal: das linhas globais a uma ecologia de saberes. In: ___ MENESES, Maria Paula (Orgs.) Epistemologias do Sul. Coimbra: Almedina, 2009.

SANTOS, Milton. Por uma geografia nova: da crítica da geografia a uma geografia crítica. 6.ed..São Paulo: EDUSP, 2008.

SEN, Amartya Kumar. Desenvolvimento como liberdade. Tradução de Laura Teixeira Motta. São Paulo: Companhia das Letras, 2000.

TYBUSCH, Jerônimo Siqueira. A sustentabilidade multidimensional como ação reflexiva para uma ecologia política pós-colonial. In. América Latina e Caribe na encruzilhada ambiental: dimensões política, jurídica e estratégica. Org. Fernando Estenssoro, (et.al.). Ijuí, RS: Unijuí, 2011.

Ecologia Política, sustentabilidade e Direito. In. Direitos emergentes na sociedade global: anuário do programa de pós-graduação em direito da UFSM. Organizador Jerônimo Tybusch. [et al.]. Ijuí, RS: Unijuí, 2013.

VEIGA, José Eli da. A emergência Socioambiental. São Paulo: SENAC, 2007.

2010.

Sustentabilidade: A legitimação de um novo valor. São Paulo: SENAC,

Submetido em: Setembro/2014

Aprovado em: Outubro/2014 